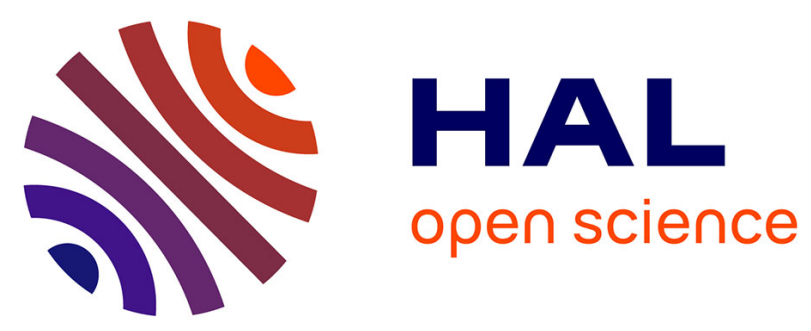

\title{
Non-human primates in outdoor enclosures: Risk for infection with rodent-borne hantaviruses
}

M. Mertens, S.S. Essbauer, A. Rang, J. Schröder, W.D. Splettstoesser, C. Kretzschmar, D.H. Krüger, M.H. Groschup, K. Mätz-Rensing, R.G. Ulrich

\section{- To cite this version:}

M. Mertens, S.S. Essbauer, A. Rang, J. Schröder, W.D. Splettstoesser, et al.. Non-human primates in outdoor enclosures: Risk for infection with rodent-borne hantaviruses. Veterinary Microbiology, 2010, 147 (3-4), pp.420. 10.1016/j.vetmic.2010.07.018 . hal-00654947

\section{HAL Id: hal-00654947 https://hal.science/hal-00654947}

Submitted on 24 Dec 2011

HAL is a multi-disciplinary open access archive for the deposit and dissemination of scientific research documents, whether they are published or not. The documents may come from teaching and research institutions in France or abroad, or from public or private research centers.
L'archive ouverte pluridisciplinaire HAL, est destinée au dépôt et à la diffusion de documents scientifiques de niveau recherche, publiés ou non, émanant des établissements d'enseignement et de recherche français ou étrangers, des laboratoires publics ou privés. 


\section{Accepted Manuscript}

Title: Non-human primates in outdoor enclosures: Risk for infection with rodent-borne hantaviruses

Authors: M. Mertens, S.S. Essbauer, A. Rang, J. Schröder, W.D. Splettstoesser, C. Kretzschmar, D.H. Krüger, M.H. Groschup, K. Mätz-Rensing, R.G. Ulrich

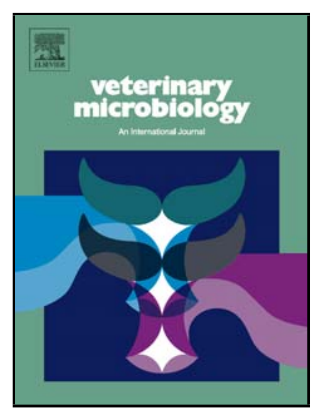

PII: S0378-1135(10)00353-6

DOI: doi:10.1016/j.vetmic.2010.07.018

Reference: VETMIC 4974

To appear in: $\quad$ VETMIC

Received date: $\quad 18-3-2010$

Revised date: $\quad 13-7-2010$

Accepted date: $\quad$ 16-7-2010

Please cite this article as: Mertens, M., Essbauer, S.S., Rang, A., Schröder, J., Splettstoesser, W.D., Kretzschmar, C., Krüger, D.H., Groschup, M.H., MätzRensing, K., Ulrich, R.G., Non-human primates in outdoor enclosures: Risk for infection with rodent-borne hantaviruses, Veterinary Microbiology (2010), doi:10.1016/j.vetmic.2010.07.018

This is a PDF file of an unedited manuscript that has been accepted for publication. As a service to our customers we are providing this early version of the manuscript. The manuscript will undergo copyediting, typesetting, and review of the resulting proof before it is published in its final form. Please note that during the production process errors may be discovered which could affect the content, and all legal disclaimers that apply to the journal pertain. 

列

.

Non-human primates in outdoor enclosures:

Risk for infection with rodent-borne hantaviruses

M. Mertens ${ }^{a \S}$, S.S. Essbauer ${ }^{b \S}$, A. Rang ${ }^{c}$, J. Schröder ${ }^{d}$, W.D. Splettstoesser ${ }^{b}$, C. Kretzschmar ${ }^{a}$, D.H. Krüger ${ }^{c}$, M.H. Groschup ${ }^{a}$, K. Mätz-Rensing ${ }^{e}$, R.G. Ulrich ${ }^{a^{*}}$ ${ }^{a}$ Friedrich-Loeffler-Institut, Institute for Novel and Emerging Infectious Diseases,

Greifswald - Insel Riems; ${ }^{b}$ Bundeswehr Institute of Microbiology, Munich; ${ }^{c}$ Institute of Medical Virology, Helmut-Ruska-Haus, University Hospital Charité, Berlin; ${ }^{d}$ Ernst-MoritzArndt-University, Insitute of Microbial Ecology, Greifswald; ${ }^{\mathrm{e}}$ German Primate Center (GPC), Göttingen, Germany.

${ }^{\S}$ Both authors contributed equally to this paper

${ }^{*}$ Corresponding author. Tel. +49 38351 7159; fax: +49 383517192. E-mail address: rainer.ulrich@fli.bund.de (Rainer G. Ulrich)

\section{ABSTRACT}

Different species of non-human primates have been exploited as animal disease models for human hantavirus infections. To study the potential risk of natural hantavirus infection of non-human primates, we investigated serum samples from non-human primates of three non-human primate species living in outdoor enclosures of the German Primate Center (GPC), Göttingen, located in a hantavirus endemic region of central Germany. For that purpose we used serological assays based on recombinant antigens of the bank vole (Myodes glareolus) transmitted Puumala virus (PUUV) and the common and field vole (Microtus arvalis, M. agrestis) associated Tula virus (TULV) which are both broadly geographically distributed in Germany. In 24 out of 251 (9.6\%) monkey sera collected in 2006 PUUV- and/or TULV-reactive immunoglobulin G ( $\lg G)$ antibodies were detected. Investigation of follow-up sera from 13 animals confirmed for two animals a 
seroconversion due to hantavirus exposure at the GPC. To prove the origin of the infection, wild rodents from the surrounding regions were analyzed by hantavirus-specific reverse transcriptase PCR analysis. In 6 of the 73 investigated bank voles and 3 of the 19 investigated Microtus spp. PUUV- and TULV-specific nucleic acid sequences, respectively, were detected. In conclusion, our investigations demonstrate for the first time natural infections of non-human primates in outdoor enclosures in Germany. These findings highlight the importance of hantavirus surveillance in those primate housings and corresponding preventive measures against wild rodents, particularly in hantavirus endemic regions.

Keywords: Non-human primates, haemorrhagic fever with renal syndrome, hantavirus, rodent, bank vole, common vole, field vole

\section{Introduction}

In natural infections hantaviruses are transmitted from persistently infected reservoir hosts such as rodents or insectivores to humans (and other non-reservoir species) by inhalation of virus-contaminated aerosols (for review see Schönrich et al., 2008). Human infections with viruses indigenous in Europe and Asia can result in haemorrhagic fevers with renal syndrome (HFRS) of different severity levels and case fatality rates (for review see Schönrich et al., 2008). As hantaviruses can cause life-threatening diseases in humans, non-human primates have been employed to establish suitable disease models. In a first attempt, three cynomolgous monkeys (Macaca fascicularis) and a chimpanzee (Pan troglodytes) were intravenously inoculated with Prospect Hill virus (PHV), a hantavirus believed to be non pathogenic to humans. Surprisingly it caused acute nephropathy with mild, transient proteinuria and azotemia (Yanagihara et al., 1988). Later, an experimental intratracheal infection of cynomolgus macaques with cell culture-adapted Puumala virus 
(PUUV) resulted in signs of lethargy followed by mild proteinuria and microhematuria and histopathological abnormalities in hantavirus RNA- and antigen-positive kidneys (Groen et al., 1995). Infection of cynomolgus macaques with a PUUV strain, that was exclusively replicated in its natural host, the bank vole (Myodes glareolus), induced some clinical symptoms such as loss of appetite, apathetic behaviour, fever, proteinuria, biochemical markers and immunological characteristics of HFRS typically observed in human patients (Klingström et al., 2002a; Sironen et al., 2008). A first indication for a naturally acquired hantavirus infection of non-human primates was reported for Macaca mulatta in China (see Clement et al., 1994).

Two Arvicolinae-associated hantaviruses, i.e. PUUV and Microtus-associated Tula virus (TULV), have a broad geographical distribution in Germany (Ulrich et al., 2004; Schmidt-Chanasit et al., 2010). Large numbers and clusters of human PUUV infections have been recorded during the outbreaks in 2005 and 2007, mainly affecting the federal states Baden-Wuerttemberg, Bavaria, Lower Saxony and North Rhine Westphalia (Essbauer et al., 2006, 2007; Hofmann et al., 2008). Whereas PUUV is causing the majority of human HFRS cases in Germany, little is known about the relevance of TULV as a human pathogen. Besides a single description of a HFRS case in north-eastern Germany (Klempa et al., 2003), TULV-specific antibodies were detected in human samples from a few seroprevalence studies (Ulrich et al., 2004; Mertens et al., unpublished data). A recent longitudinal study revealed a sympatric occurence of TULV in common (Microtus arvalis) and field voles (M. agrestis) from Sennickerode, district Göttingen, federal state of Lower Saxony (Schmidt-Chanasit et al., 2010). As this site is in close vicinity of the German Primate Center (see Fig. 1) we wanted to prove if non-human primates in outdoor enclosures are at risk to get infected by hantaviruses circulating in the vole populations close to the husbandry. For this purpose we investigated the prevalence of hantavirus-reactive antibodies in three different simian 
species and compared the findings with the results from molecular hantavirus

80 investigations in the local rodent populations.

81

\section{Materials and methods}

\subsection{Breeding colonies of non-human primates}

The German Primate Center (GPC) is housing and breeding the Old World monkey species Macaca mulatta, M. fascicularis and Papio anubis in in- and outdoor units. Each unit is composed of an indoor area, a heated and/or roofed outdoor room and a large outdoor exhibition bordered by fences. Contacts to any other animal species except wild birds or small mammals are efficiently prevented. About one half of the investigated animals were born at the GPC, whereas the other animals originated from other husbandries in Germany, France or the USA. All animals are kept in accordance with the guidelines of the European Union for the accommodation and care of animals used for experimental and other scientific purposes (2007/526/EG, D-AFF 008-EWG). The primate husbandry is controlled by local and regional veterinary authorities in accordance with the German Animal Protection Law. All procedures are supervised by an animal welfare officer and the ethical committee for experiments using animals in the federal state of Lower Saxony. During the yearly routine health check 295 serum samples were collected in 1999 -2007 from 254 monkeys including 211 rhesus macaques ( $M$. mulatta), 26 cynomolgus monkeys ( $M$. fascicularis) and 17 olive baboons ( $P$. anubis). This panel contains also serum samples from two M. mulatta and one M. fascicularis, that died in 2004 or 2005 due to tularemia. The blood collection was carried out in Ketamin-anesthesia (Ketavet®, Pfizer, Karlsruhe, Germany) in a dosage of $10 \mathrm{mg} / \mathrm{kg}$.

\subsection{Serological analysis of monkey serum samples}


104 The serological investigations of the samples for hantavirus-specific antibodies were

105 performed following the recently described scheme for seroepidemiological investigations

106 (Mertens et al., 2009). Briefly, the sera were initially investigated in parallel by PUUV- and

107 TULV-based screening IgG-ELISAs. For confirmation, ELISA-positive sera were tested in

108 the corresponding PUUV- and TULV-IgG immunoblot tests (Mertens et al., 2009; Schmidt-

109 Chanasit et al., 2010), but using a horseradish peroxidase-labeled rabbit anti-monkey lgG

110 (Heavy and Light chain, $\mathrm{H}+\mathrm{L})$ (Nordic Immunology, Offenbach, Germany). Finally, selected

111 ELISA-reactive, immunoblot-confirmed sera were investigated by chemiluminescence

112 focus reduction neutralization test (cFRNT) using PUUV, strain Sotkamo, TULV, strain

113 Moravia, and Apodemus flavicollis-borne Dobrava-Belgrade virus (DOBV), strain Slovenia,

114 as a control (Heider et al., 2001).

\subsection{Rodent trapping and hantavirus analysis}

117 The trapping of rodents in Sennickerode and at an area of approximately $30,000 \mathrm{~m}^{2}$

118 around the GPC of Göttingen, both in district Göttingen (see Fig. 1), as well as the TULV

119 investigations of Microtus arvalis and $M$. agrestis from Sennickerode have already been

120 described in detail (Kaysser et al., 2008; Schmidt-Chanasit et al., 2010). Hantavirus-S-

121 segment-specific reverse transcriptase-PCR (RT-PCR) of animals trapped around the

122 GPC and of bank voles from Sennickerode followed previously described detailed

123 protocols (Essbauer et al., 2006; Schmidt-Chanasit et al., 2010). Retrieved novel partial

124 PUUV and TULV S-segment sequences were submitted to GenBank with accession 125 numbers GU300138-GU300143 and GU300135-GU300137, respectively.

\section{Results}

128 Using recombinant PUUV- and TULV-antigen-based IgG screening ELISA and 129 confirmation immunoblot assays, 24 of the $251(9.6 \%)$ investigated animal serum samples 
130 collected during 2006 were positive for hantavirus-specific IgG antibodies with at least one

131 of the used antigens (Table 1). Out of these 24 samples 17 exclusively reacted with PUUV

132 antigen, three with TULV antigen and four with both antigens to the same extent. A total of

13316 of the $209(7.7 \%)$ sera from 13 female and three male rhesus macaques ( $M$. mulatta)

134 were seropositive with isolated reaction to PUUV antigen for 13 samples, to TULV antigen

135 for two samples and a cross-reactivity to both antigens for one sample. In the olive

136 baboons ( $P$. anubis) serum panel 6 of $17(35.3 \%)$ were reactive with at least one of the

137 antigens. Out of these 6 samples, with five of six originating from female animals, three

138 reacted with the PUUV, one with TULV and two with both antigens. The level of

139 seroreactivity in the cynomolgus monkey (M. fascicularis) panel was $8.0 \%(2 / 25)$ with one

140 serum reacting only with PUUV antigen and one with the two antigens. The two

141 seroreactive sera originated from female individuals (Table 1). Subsequent analysis of five

142 selected ELISA-positive, immunoblot-confirmed sera from M. mulatta by PUUV, TULV and

143 DOBV cFRNT revealed one PUUV/TULV cross-reactive, but DOBV non-reactive serum

144 originating from a six year-old female animal (\#2116) born at the GPC. The endpoint titer

145 to PUUV (640) was slightly higher than that to TULV (320).

146 Next, follow-up sera of 12 animals including 11 M. mulatta and one M. fascicularis,

147 which were in the initially investigated serum samples from 2006 positive, were tested in

148 the same way as described above (Table 1). From four M. mulatta (\#4986, \#9290, \# 9796

149 and \#9821) all serum samples were found to be positive, with at least one antigen. Four

150 additional M. mulatta (\#9291, \#9292, \#12083, \#12103) demonstrated an initially negative

151 or equivocal sample with all corresponding following samples being positive. The

152 remaining three $M$. mulatta showed an oscillation of positive and negative reactivity

153 (\#2148, \#13032) or vice versa (\#11660). All three follow-up samples from M. fascicularis

154 \#9858 reacted with both antigens. Finally, the medical records were retrospectively

155 checked for potential indications of a hantavirus infection. None of the seropositive animals 
156 developed symptoms typical for a hantavirus infection like apathy, vomiting, diarrhea or

157 hematuria. At the time of blood sample collection a complete health check was done. All 158 animals were clinically healthy and kidney and liver enzymes were within the normal 159 range. Six of the seropositive animals died during the investigation period. There was no 160 correlation between the cause of death and the former hantavirus infection. Two animals 161 (\#2039, \#2242) had to be humanly euthanasized because of severe injuries after heavy 162 ranking fights. One animal died after severe aspiration pneumonia (\#9292). One of the baboons (\#13315) died because of several changes due to old age. Systemic echinococcosis was the cause of death in the last two animals (\#9858, \#9870). The histological samples of the deceased monkeys were screened for signs of a hantavirus infection but none of the animals showed kidney alterations in form of interstitial nephritis. In addition, serum samples from two $M$. mulatta and one $M$. fascicularis, that died due to tularemia, tested in the PUUV and TULV ELISA revealed for all investigated samples of one M. mulatta PUUV-reactive antibodies (Table 1; \#9411). The other two 170 animals did not show any reactivity in the PUUV and TULV IgG screening ELISAs (data 171 not shown). Interestingly, in a recent study TULV infections have been described in $M$. arvalis and $M$. agrestis from Sennickerode, district Göttingen, about $20 \mathrm{~km}$ apart from the GPC 174 (Schmidt-Chanasit et al. 2010; see Fig. 1). In addition, herein we investigated lung tissue samples from 60 bank voles (M. glareolus) from the same trapping site. Novel partial

176 PUUV S-segment-specific fragments were detected by RT-PCR in 6 of the lung samples 177 (10\%). These sequences are closely related to each other, but can be differentiated at the 178 nucleotide level from PUUV sequences originating from other regions in Germany, e.g. 179 Baden-Wuerttemberg, northern and southern Bavaria and Cologne (see supplementary 180 Table 1). 

13 M. glareolus, have been trapped in the immediate vicinity and surrounding coppice of

183 the GPC (Kaysser et al., 2008). RT-PCR analysis of lung tissue samples from M. arvalis, M. agrestis and M. glareolus revealed 3/11 (27.3\%) TULV-positive $M$. arvalis, but no indication for hantavirus infections in field and bank voles (data not shown). A pairwise comparison of the derived TULV sequences from Göttingen revealed a close relationship

187 to the TULV sequences recently described from Sennickerode (see supplementary Table 188 2).

\section{Discussion}

191 Spillover infections of non-reservoir rodent species are believed to be a rare event

192 (Klingström et al., 2002b), but represent a pre-requisite for a subsequent establishment of

193 a transmission cycle in a novel reservoir host as well as genetic reassortment processes

194 between different hantaviruses. In line, detection of multiple spillover infections of $M$.

195 agrestis with $M$. arvalis-associated TULV has been discussed as the beginning

196 establishment of a novel reservoir host transmission cycle (Schmidt-Chanasit et al., 2010).

197 Similarly, multiple spillover infections of $A$. agrarius-borne DOBV to A. flavicollis have been

198 observed in northern Germany (Schlegel et al., 2009). Detection of hantavirus-reactive 199 antibodies in carnivores, like foxes, cats and dogs, and in other wildlife species, such as 200 wild moose, demonstrated the infectivity of the pathogen for other species (for review see 201 Zeier et al. 2005).

202 Here we demonstrated a stable hantavirus seropositivity over a period of up to 203 seven years in all investigated longitudinal samples of six animals including five M. mulatta 204 (\#4986, \#9290, \#9411, \#9796, \#9821) and one M. fascicularis (\#9858). These data 205 suggest a long-term immunity induced by naturally acquired hantavirus infection in these 206 primates. Interestingly, for two rhesus monkeys (\#9291 and \#12083) an obvious 
seroconversion for PUUV was observed between 2003/2005 and 2005/2006 suggesting an exposure to PUUV at the GPC during 2003-2006. Due to the hantavirus outbreak in 209 Germany in 2005 with a total of 447 HFRS cases and an increased number of cases $210(\mathrm{n}=11)$ in the district Göttingen (Robert Koch-Institut: SurvStat, www.rki.de; data as of 211 February 10, 2009), one may speculate on a high infection burden in the bank vole 212 populations resulting in increased numbers of human cases and the potential exposure to 213 some primates in the outdoor enclosures. The serological findings of TULV-reactive 214 antibodies in $M$. mulatta animal \#9292 may also suggest a seroconversion with an exposure in 2003 or before. Although for some seroreactive monkeys in this study the exposure and infection with PUUV, TULV or PUUV/TULV-cross-reactive hantaviruses, i.e.

217 PHV (Chu et al., 1995), might have occurred at their breeding origin at other places in 218 Germany, France or the USA, this, nevertheless, again confirms the susceptibility of non219 human primates, i.e. M. mulatta, M. fascicularis and $P$. anubis for natural hantavirus 220 infection. symptoms which resemble those observed in humans (Yanagihara et al., 1988; Groen et al., 1995; Klingström et al., 2002a). A retrospective analysis of the clinical records of all animals investigated here did not show hints for clinical symptoms after hantavirus exposure. In addition, for three animals that died in 2004/2005 due to tularemia no signs of a co-morbidity of hantavirus and Francisella infections could be found. Additional studies 227 are needed to prove whether naturally acquired hantavirus infections in different non228 human primate species may result in an asymptomatic or mild course of disease with 229 unspecific symptoms.

The herein reported detection of hantavirus-reactive antibodies, and a 231 seroconversion in particular, in non-human primates in outdoor enclosures and the parallel 232 demonstration of PUUV- and TULV-infected reservoir hosts in the surroundings suggest 
233 that infection events occurred in the past. The exposure of monkeys in the GPC to wild

234 rodents from the surroundings was previously already suggested due to the death of a 235 group of cynomolgus monkeys (M. fascicularis) and the parallel detection of Francisella 236 tularensis in rodents from the surroundings (Mätz-Rensing et al., 2007; Kaysser et al., 237 2008).

238 In conclusion, this is, to our knowledge, the first report of natural infections of non239 human primates in outdoor enclosures in Europe raising important questions on future 240 hantavirus surveillance in such husbandries. In addition, the results of the study 241 accentuate the need of an efficient rodent combat and management in primate 242 husbandries to protect susceptible primate species from hantavirus infection.

244 Acknowledgments

245 The excellent technical assistance of Brigitte Pohl, Angelika Lander (Berlin), Dörte 246 Kaufmann (Greifswald-Insel Riems), Kerstin Weiß, Aileene Lorber and Astrid Thomas 247 (Munich) is kindly acknowledged.

\section{References}

250 Chu, Y.K., Jennings, G., Schmaljohn, A., Elgh, F., Hjelle, B., Lee, H.W., Jenison, S., 251 Ksiazek, T., Peters, C.J., Rollin, P., et al., 1995. Cross-neutralization of hantaviruses with 252 immune sera from experimentally infected animals and from hemorrhagic fever with renal 253 syndrome and hantavirus pulmonary syndrome patients. J. Infect. Dis. 172, 1581-1584.

254 Clement, J., Mc Kenna, P., Leirs, H., Verhagen, R., Lefevre, A., Song, G., Tkachenko, E., 255 van der Groen, G. Hantavirus infections in rodents. In : (Horzinek, ed) Virus infections of 256 Rodents and lagomorphs, 5th Volume in a series (Osterhaus, ed) "Virus infections in 257 Vertebrates" Elsevier Science BV. Amsterdam 1994: 295-316. (ISBN 0-444-81909-6). 
258 Essbauer, S., Schmidt, J., Conraths, F.J., Friedrich, R., Koch, J., Hautmann, W., Pfeffer, 259 M., Wölfel, R., Finke, J., Dobler, G., Ulrich. R., 2006. A new Puumala hantavirus subtype 260 in rodents associated with an outbreak of Nephropathia epidemica in South-East Germany 261 in 2004. Epidemiol. Infection 134, 1333-1344.

262 Essbauer, S.S., Schmidt-Chanasit, J., Madeja, E.L., Wegener, W., Friedrich, R., Petraityte, 263 R., Sasnauskas, K., Jacob, J., Koch, J., Dobler, G., Conraths, F.J., Pfeffer, M., Pitra, C., 264 Ulrich, R.G., 2007. Nephropathia epidemica outbreak in a metropolitan area, Germany. 265 Emerg. Infect. Dis. 13, 1271-1273.

266 Groen, J., Gerding, M., Koeman, J.P., Roholl, P.J., van Amerongen, G., Jordans, H.G., 267 Niesters, H.G., Osterhaus, A.D., 1995. A macaque model for hantavirus infection. J. Infect. 268 Dis. 172, 38-44.

269 Heider, H., Ziaja, B., Priemer, C., Lundkvist, Å., Neyts, J., Krüger, D.H., Ulrich. R., 2001. A 270 chemiluminescence detection method of hantaviral antigens in neutralisation assays and 271 inhibitor studies. J. Virol. Methods 96, 17-23.

272 Hofmann, J., Meisel, H., Klempa, B., Vesenbeckh, S.M., Beck, R., Michel, D., Schmidt273 Chanasit, J., Ulrich, R.G., Grund, S., Enders, G., Krüger D.H., 2008. Molecular 274 epidemiology of a large hantavirus outbreak in Germany, 2007. Emerg. Infect. Dis. 14, $275 \quad 850-852$.

276 Kaysser, P., Seibold, E., Mätz-Rensing, K., Pfeffer, M., Essbauer, S., Splettstoesser, W.D., 277 2008. Re-emergence of tularemia in Germany: presence of Francisella tularensis in 278 different rodent species in endemic areas. BMC Infect. Dis. 8, 157.

279 Klempa, B., Meisel, H., Räth, S., Bartel, J., Ulrich, R., Krüger D.H., 2003. Occurrence of 280 renal and pulmonary syndrome in a region of northeast Germany where Tula virus 281 circulates. J. Clin. Microbiol. 41, 4894-4897. 
282 Klingström, J., Plyusnin, A., Vaheri, A., Lundkvist, Å., 2002a. Wild-type Puumala 283 hantavirus infection induces cytokines, C-reactive protein, creatinine, and nitric oxide in 284 cynomolgus macaques. J. Virol. 76, 444-449.

285 Klingström, J., Heyman, P., Escutenaire, S., Sjölander, K.B., De Jaegere, F., Henttonen, 286 H., Lundkvist, A., 2002b. Rodent host specificity of European hantaviruses: evidence of 287 Puumala virus interspecific spillover. J. Med. Virol. 68, 581-588.

288 Mätz-Rensing, K., Floto, A., Schrod, A., Becker, T., Finke, E.J., Seibold, E., Splettstoesser, 289 W.D., Kaup, F.J., 2007. Epizootic of tularemia in an outdoor housed group of cynomolgus 290 monkeys (Macaca fascicularis). Vet. Pathol. 44, 327-334.

291 Mertens, M., Wölfel, R., Ullrich, K., Yoshimatsu, K., Blumhardt, J., Römer, I., Esser, J., 292 Schmidt-Chanasit, J., Groschup, M.H., Dobler, G., Essbauer, S.S., Ulrich, R.G., 2009. 293 Seroepidemiological study in a Puumala virus outbreak area in South-East Germany. Med. 294 Microbiol. Immunol. 198, 83-91.

295 Schlegel, M., B. Klempa, B. Auste, M. Bemmann, J. Schmidt-Chanasit, T. Büchner, M.H. 296 Groschup, Meier, M. Buschmann A., Zoller, H. Krüger, D.H. and Ulrich R.G.. 2009. 297 Dobrava-Belgrade virus spillover infections, Germany. Emerging Infectious Diseases $298 \quad 15: 2017-2020$.

299 Schmidt-Chanasit, J., Essbauer, S., Petraityte, R., Yoshimatsu, K., Tackmann, K., 300 Conraths, F.J., Sasnauskas, K., Arikawa, J., Thomas, A., Pfeffer, M., Scharninghausen, 301 J.J., Splettstoesser, W., Wenk, M., Heckel, G., Ulrich, R.G., 2010. Extensive host sharing 302 of Central European Tula virus. J. Virol. 84, 459-474

303 Schönrich, G., Rang, A., Lütteke, N., Raftery, M.J., Charbonnel, N., Ulrich, R.G., 2008. 304 Hantavirus-induced immunity in rodent reservoirs and humans. Immunol. Rev. 225, 163305189.

306 Sironen T, Klingström J, Vaheri A, Andersson LC, Lundkvist A, Plyusnin A., 2008. 307 Pathology of Puumala hantavirus infection in macaques. PLoS One 21; e3035. 
308 Ulrich, R., Meisel, H., Schütt, M., Schmidt, J., Kunz, A., Klempa, B., Niedrig, M., Kimmig, 309 P., Pauli, G., Krüger, D.H., Koch, J., 2004. Verbreitung von Hantavirusinfektionen in 310 Deutschland. Bundesgesundheitsbl. Gesundheitsforsch. Gesundheitssch. 47, 661-670.

311 Yanagihara, R., Amyx, H.L., Lee, P.W., Asher, D.M., Gibbs Jr., C.J., Gajdusek D.C., 1988.

312 Experimental hantavirus infection in nonhuman primates. Arch. Virol. 101, 125-130.

313 Zeier, M., Handermann, M., Bahr, U., Rensch, B., Müller, S., Kehm, R., Muranyi, W., 314 Darai, G., 2005. New ecological aspects of hantavirus infection: a change of a paradigm 315 and a challenge of prevention - a review. Virus Genes 30, 157-180.

\section{Legends to Figures}

318 Fig. 1. Maps of Germany showing the federal state Lower Saxony (marked in black; A) and 319 the localization of the rodent trapping sites at the German Primate Center (GPC) and in 320 Sennickerode (SEN) in the administrative district Göttingen (B). 
Table 1. Serological reactivity of non-human primate sera from the German Primate Center (GPC) in Puumala virus (PUUV) and Tula virus (TULV) IgG-ELISA and -immunoblot assay (IB).

\begin{tabular}{|c|c|c|c|c|c|c|}
\hline \multicolumn{5}{|c|}{ Animal description } & \multicolumn{2}{|c|}{$\begin{array}{c}\text { Results of IgG- } \\
\text { ELISA/IB }^{\mathrm{b}}\end{array}$} \\
\hline Species & $\begin{array}{c}\text { Animal } \\
\text { no. }\end{array}$ & Origin & $\begin{array}{c}\text { Age }^{\mathrm{a}} \text { (years)/ sex/ } \\
\text { year of death }\end{array}$ & $\begin{array}{l}\text { Year of } \\
\text { blood } \\
\text { collection }\end{array}$ & PUUV & TULV \\
\hline Macaca mulatta & 2039 & GPC & 8/f/2008 & 2006 & - & + \\
\hline Macaca mulatta & 2116 & GPC & $6 / \mathrm{f}$ & 2006 & + & + \\
\hline \multirow{4}{*}{ Macaca mulatta } & \multirow{4}{*}{2148} & \multirow{4}{*}{ GPC } & $1 / f$ & 2002 & $E$ & + \\
\hline & & & $2 / f$ & 2003 & - & - \\
\hline & & & $4 / \mathrm{f}$ & 2005 & + & - \\
\hline & & & $5 / f$ & 2006 & $(+)$ & - \\
\hline Macaca mulatta & 2242 & GPC & $3 / f / 2008$ & 2006 & + & - \\
\hline Macaca mulatta & 2305 & GPC & $2 / \mathrm{m}$ & 2006 & + & - \\
\hline Macaca mulatta & 2323 & GPC & $1 / \mathrm{f}$ & 2006 & + & - \\
\hline \multirow{3}{*}{ Macaca mulatta } & \multirow{3}{*}{4986} & \multirow{3}{*}{$\begin{array}{l}\text { USA, } \\
\text { since } 1998 \text { in GPC }\end{array}$} & $13 / \mathrm{m}$ & 2005 & + & + \\
\hline & & & $14 / \mathrm{m}$ & 2006 & + & + \\
\hline & & & $15 / \mathrm{m}$ & 2007 & + & + \\
\hline \multirow{3}{*}{ Macaca mulatta } & \multirow{3}{*}{9290} & \multirow{3}{*}{$\begin{array}{l}\text { Strasbourg, } \\
\text { since } 1998 \text { in GPC }\end{array}$} & $6 / f$ & 2003 & + & + \\
\hline & & & $8 / 4$ & 2005 & + & $E$ \\
\hline & & & $9 / \mathrm{f}$ & 2006 & + & - \\
\hline \multirow{4}{*}{ Macaca mulatta } & \multirow{4}{*}{9291} & \multirow{4}{*}{$\begin{array}{l}\text { Strasbourg, } \\
\text { since } 1998 \text { in GPC }\end{array}$} & $7 / f$ & 2003 & - & - \\
\hline & & & $9 / f$ & 2005 & + & - \\
\hline & & & $10 / \mathrm{f}$ & 2006 & + & - \\
\hline & & & $11 / \mathrm{f}$ & 2007 & + & $\mathrm{E}$ \\
\hline \multirow{4}{*}{ Macaca mulatta } & \multirow{4}{*}{9292} & \multirow{4}{*}{$\begin{array}{l}\text { Strasbourg, } \\
\text { since } 1998 \text { in GPC }\end{array}$} & $11 / f / 2008$ & 2003 & - & $\mathrm{E}$ \\
\hline & & & $13 / f / 2008$ & 2005 & - & + \\
\hline & & & $14 / f / 2008$ & 2006 & - & + \\
\hline & & & $15 / f / 2008$ & 2007 & - & + \\
\hline
\end{tabular}




\begin{tabular}{|c|c|c|c|c|c|c|}
\hline \multirow{4}{*}{ Macaca mulatta } & \multirow{4}{*}{9796} & \multirow{4}{*}{ GPC } & $4 / f$ & 2003 & + & - \\
\hline & & & $6 / f$ & 2005 & + & - \\
\hline & & & $7 / f$ & 2006 & + & - \\
\hline & & & $8 / f$ & 2007 & + & - \\
\hline \multirow{4}{*}{ Macaca mulatta } & \multirow{4}{*}{9821} & \multirow{4}{*}{ GPC } & $4 / f$ & 2003 & + & + \\
\hline & & & $6 / f$ & 2005 & + & + \\
\hline & & & $7 / f$ & 2006 & + & - \\
\hline & & & $8 / f$ & 2007 & + & - \\
\hline \multirow{4}{*}{ Macaca mulatta } & \multirow{4}{*}{11660} & \multirow{4}{*}{ GPC } & $1 / f$ & 2003 & - & - \\
\hline & & & $3 / f$ & 2005 & - & - \\
\hline & & & $4 / f$ & 2006 & + & - \\
\hline & & & $5 / f$ & 2007 & - & - \\
\hline \multirow{3}{*}{ Macaca mulatta } & \multirow{3}{*}{12083} & \multirow{3}{*}{ GPC } & $2 / f$ & 2005 & - & - \\
\hline & & & $3 / f$ & 2006 & + & - \\
\hline & & & $4 / f$ & 2007 & + & - \\
\hline \multirow{3}{*}{ Macaca mulatta } & \multirow{3}{*}{12103} & \multirow{3}{*}{ GPC } & $2 / f$ & 2005 & $E$ & - \\
\hline & & & $3 / f$ & 2006 & + & - \\
\hline & & & $4 / f$ & 2007 & + & - \\
\hline \multirow{2}{*}{ Macaca mulatta } & \multirow{2}{*}{13032} & \multirow{2}{*}{ GPC } & $1 / \mathrm{m}$ & 2006 & + & - \\
\hline & & & $2 / \mathrm{m}$ & 2007 & - & - \\
\hline \multirow{3}{*}{ Macaca mulatta } & \multirow{3}{*}{9411} & \multirow{3}{*}{$\begin{array}{l}\text { Strasbourg, since } \\
1998 \text { GPC }\end{array}$} & $10 / \mathrm{m} / 2004$ & 2001 & + & - \\
\hline & & & $12 / \mathrm{m} / 2004$ & 2003 & + & - \\
\hline & & & $13 / \mathrm{m} / 2004$ & 2004 & + & - \\
\hline \multirow{3}{*}{ Macaca fascicularis } & \multirow{3}{*}{9858} & \multirow{3}{*}{$\begin{array}{l}\text { Marburg, } \\
\text { since } 1999 \text { in GPC }\end{array}$} & $11 / f / 2009$ & 1999 & + & + \\
\hline & & & $15 / f / 2009$ & 2003 & + & + \\
\hline & & & $18 / f / 2009$ & 2006 & + & + \\
\hline Macaca fascicularis & 9870 & $\begin{array}{l}\text { Marburg, } \\
\text { since } 1999 \text { in GPC }\end{array}$ & $8 / f / 2007$ & 2006 & + & - \\
\hline Papio anubis & 13300 & $\begin{array}{l}\text { University Munich, } \\
\text { since } 2005 \text { in GPC }\end{array}$ & $2 / m$ & 2006 & + & - \\
\hline Papio anubis & 13298 & University Munich, & $5 / f$ & 2006 & + & - \\
\hline
\end{tabular}




\begin{tabular}{|c|c|c|c|c|c|c|}
\hline & & since 2005 in GPC & & & + \\
\hline Papio anubis & 13307 & $\begin{array}{l}\text { University Munich, } \\
\text { since 2005 in GPC }\end{array}$ & $3 / f$ & 2006 & + \\
\hline Papio anubis & 13311 & $\begin{array}{l}\text { University Munich, } \\
\text { since 2005 in GPC }\end{array}$ & $14 / f$ & 2006 & - & + \\
\hline Papio anubis & 13312 & $\begin{array}{l}\text { University Munich, } \\
\text { since 2005 in GPC }\end{array}$ & $7 / f$ & 2006 & + & + \\
\hline Papio anubis & 13315 & $\begin{array}{l}\text { University Munich, } \\
\text { since 2005 in GPC }\end{array}$ & $20 / f / 2009$ & 2006 & + & - \\
\hline
\end{tabular}

${ }^{\mathrm{a}} \mathrm{Age}$ at the time point of blood collection.

${ }^{b}$ The serological investigations and the subsequent result evaluations were performed following the recently described scheme for seroepidemiological investigations using PUUV and TULV IgG-ELISA as screening tests and the corresponding IgG-IB for confirmation (Mertens et al., 2009).

-, negative, i.e. "negative" result in the ELISA screening test

+ , positive, i.e. "positive" or "weakly positive" result in one test and "positive" result in the other test

$(+)$, weakly positive, i.e. reaction in both tests "weakly positive" or "weakly positive"/"positive" in one test and "equivocal" in the other

$\mathrm{E}$, equivocal, i.e. "equivocal" result in both tests.

$\mathrm{m}$, male; f, female. 
Figure

Fig. 1

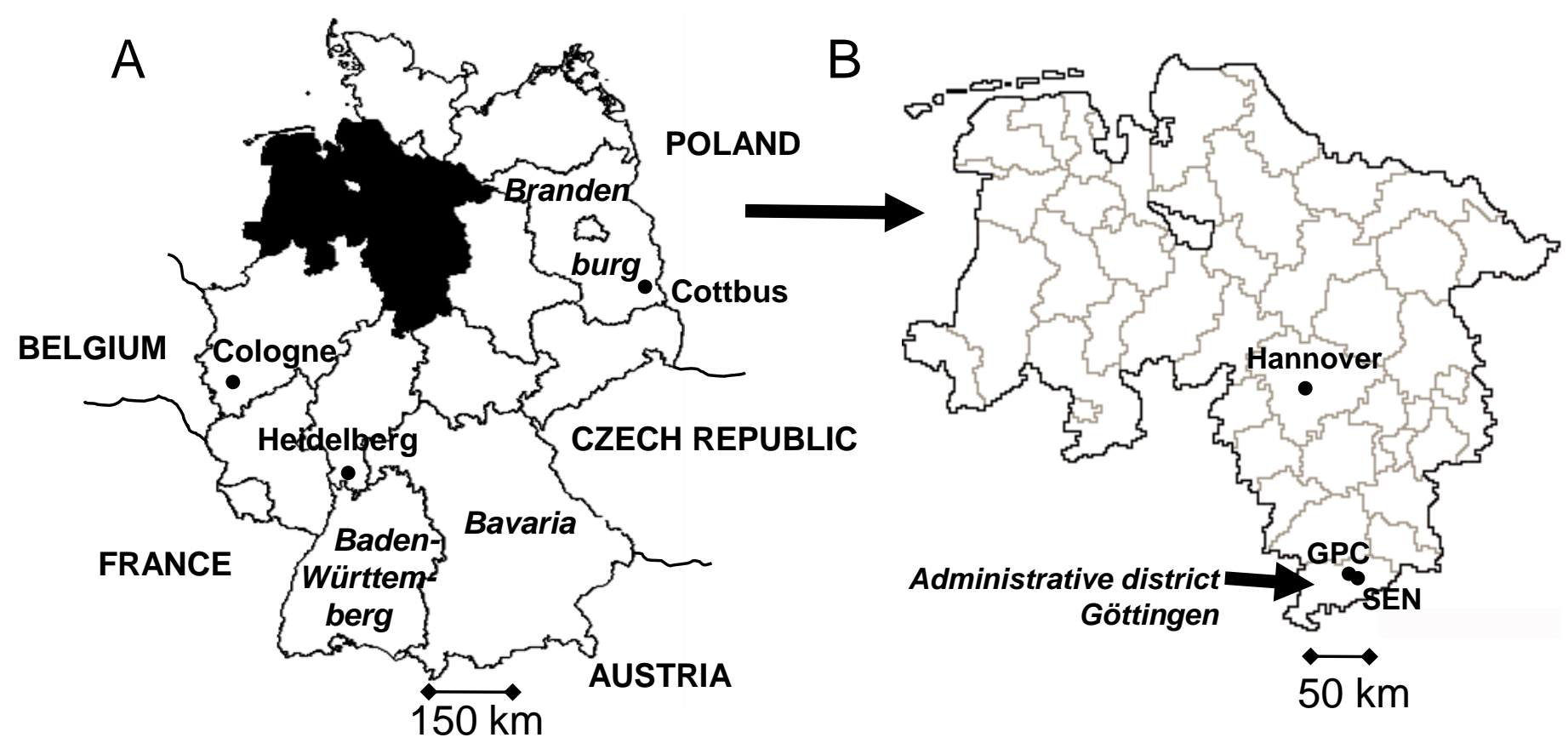

